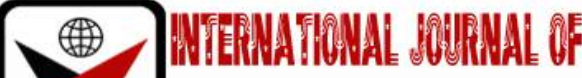

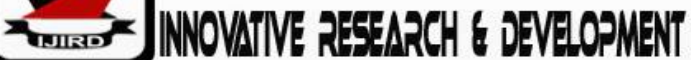

ISSN 2278 - 0211 (Online)

\section{Innovation Capability and Market Share: The Moderating Effect of Marketing Capability}

\begin{tabular}{c} 
Abiodun B. Onamusi \\
\hline Ph.D. Student, Department of Business Administration \& Marketing, \\
Babcock University, Ilishun-Remo, Nigeria \\
Dr. Olalekan U. Asihkia \\
Professor, Department of Business Administration \& Marketing, \\
Babcock University, Ilishun-Remo, Nigeria \\
Dr. Grace O. Makinde \\
Lecturer, Department of Business Administration \& Marketing, \\
Babcock University, Ilishun-Remo, Nigeria
\end{tabular}

\begin{abstract}
:
The performance of manufacturers of baby-care products in Nigeria experienced 1\% improvement between 2017 and 2018 and this is in spite of the 36.9\% birth rate within this period. Empirical submissions have linked the cause of this performance in the baby-care industry to primarily the macroeconomic conditions in Nigeria. Literatures advocate that to flourish in a changing environment, organizations need to employ competencies (innovation and marketing) that can adjust well with such turbulent environment. Hence, this study examined the effect of innovation capability on market performance. In addition it evaluated the moderating effect of marketing capability on the interaction between innovation capability and market performance. To achieve these objectives, the study employed a cross-sectional survey design and a sample of 232 employees of four manufacturers of baby-diapers in Lagos State, Nigeria. Through a validated questionnaire, a moderated regression analysis to test two-way interaction hypotheses was conducted, and the results show that innovation capability has a significant positive effect on market share $(R 2=0.221, F(1,233)=66.279$, $\beta=0.460, t=8.141, p=0.000)$. Further analysis shows that innovation capability explained the increase experienced in market share with the introduction marketing capability as a moderator $(\Delta R 2=0.02, \Delta F(1,232)=6.205, p=0.013)$. This finding suggests that managers of manufacturing companies in diaper production in Nigeria should invest more in developing an innovative high-level capability that would help their firms to improve their market performance. Moreover, pay attention to developing more dynamic marketing capability from an outside-in perspective to enhance the overall organizational performance.
\end{abstract}

Keywords: Baby-diaper industry, marketing, innovation, performance, Lagos State

\section{Introduction}

Global performance of manufacturers in baby-care product market showed that the market was value above 87 billion dollars as at 2018 and it is expected to reach 108 billion by 2025 (Zion market report, 2018). The report further shows regional share of the global market share; North America 20.92\%, Europe 24.74\%, Asia Pacific 29.61\%, South America, Middle-East and African accounted for 24\%. These figures shows how uneven each region have performed. Africa continues to experience unstable growth rates, due to economic (policy flip-flops), financial crises, coupled with political and security concerns (Euromonitor, 2018). Consequently, this has hampered the growth experienced in the baby-care industry. For example, the continent boast of the lowest per capital diaper usage for babies' age 0-3yrs to be 339 (of the 339, Nigeria account for a meagre 89) compared to Israel's 955 in the same region (Euromonitor, 2018). This is despite the increasing birth rates experience in the continent. The harsh economic conditions experienced in Nigeria have further presented a challenging business environment for manufacturers in the country.

Although the diaper category of baby-care product experienced 1\% improvement in market share in 2017 when compared with 2016, with a retail volume CAGR of 6\% (Euromonitor, 2018) respectively. However per capita consumption remains very low compared with countries in the same region and despite birth rate of 36.9\% in 2017 (NPC, 2018 ), likewise the enormous costs associated with raw materials, product development, marketing, and rigid legislations are restraining the babycare market from moving ahead (Inkwood report, 2017).

In the face of these country-specific challenges, scholars have positioned the RBV fundamentals. Been an inside-out perspective, RVB advocators suggested that firms can deploy their core competences to cope and take advantage of a dynamic 
environment (Kim, Shin \& Min, 2016; Onamusi, Asikhia \& Makinde, 2019; Zhang \& Hartley, 2018). Such capabilities include the ability to innovate both management and technological processes (Abiodun, 2017; Ukpabio, Oyebisi \& Siyanbola, 2017) and abilities to conduct active market sensing, communication, planning and implementation (Balarebe, Lily \& Shamsul, 2017; Day, 2014; Mu, Bao, Sekhon, Qi \& Love, 2018).

Many research efforts in the area of innovation have dealt with issues such as the role of innovation capability, its relationship with performance, implementation, and effect of rival innovativeness in different countries and in diverse sectors of the economy (Atalay, Anafarta, \& Sarvan, 2013; Wang, \& Miao, 2015; Foroudi, Jin, Gupta, Melewar, \& Foroudi, 2016; Lee, Lee, \& Garrett, 2017; Ngo, Bucic, Sinha, \& Lu, 2019; Fallah, Jafariyan, \& Savabieh, 2018). Although, Innovation is extensively regarded by scholars as critical for sustaining competitive advantage in dynamic environment (Bowen, Rostami, \& Steel, 2010), yet findings from these studies provided mixed results which can be attributed the context in which the studies were conducted and the issues addressed. Even though much work has been done to date, more studies are needed to ascertain the effect of innovation capability on market performance(measured as market share) of manufacturers in Baby-care product industry in Lagos State, Nigeria. Furthermore, scholars have paid less concern for the moderating effect of marketing capability components for example market sensing, communication, and implementation. Hence suggesting another need for this study. In view of this development, this study is focused on evaluating the moderating effect of marketing capability on the interactions between innovation capability and market share of the manufacturer of Baby-diaper in Lagos State, Nigeria.

\section{Literature Review}

\subsection{Theoretical Framework and Hypotheses Development}

A number of studies have been done to appraise existing theories and to enhance the understanding of innovation capability and marketing capability (Abiodun, 2017; Adeoye, Agbawodikeizu \& Egwakhe, 2019; Fallah et al., 2018; Mohammed, Norshahrizan \& Wan-Ahmad, 2017; Mu., 2015; Mu et al., 2018; Ngo \& O'Cass, 2012; Oluwole Binuyo, Ekpe \& Oloyede Binuyo, 2019; Takata, 2016; Talaja, 2013; Tuan, Nhan, Giang \& Ngoc, 2016; Ukpabio et al., 2017). However, this study draws on two perspectives; dynamic capability theory (DCT) and contingency theory (CT), to substantiate the effect of innovation capability on market share of manufacturers of baby diaper in Lagos state, Nigeria and to ascertain the moderating effect of marketing capability dimensions on the interaction between innovation capability and market share. These two perceptions are of precise significance to this study.

First, DCT submission is centered on the need for firms to have the capacity to integrate, develop internal and external competences that are peculiar to it and consistently reconfigure these competencies to stand a change at achieving competitive advantage in a dynamic environment (Kaur \& Mehta, 2017; Teece, 2014a). This suggest that there must be a direct correlation with the ownership of dynamic internal-external capabilities and superior firm performance (Chukwuemeka \& Onuoha, 2018; Lee, Wu, Kuo, \& Li, 2016; Zhang \& Hartley, 2018). Second, according to Boyd, Takac-Haynes, Hitt, Bergh and Ketchen (2011), CT was built on the premise that beyond the organization, some exigencies influences the organization's performance. Implying that when an organization can fit itself with contingent factors (culture, strategy, technology, structure, and environment), such alignment will guarantee improved performance(Monday, Akinola, Ologbenla, \& Aladeraji, 2015; Nwonu, Agbaeze, Obi-Anike, 2017;Binti \& Bin Zainuddin, 2016; Monday et al., 2015; Ngo et al., 2019; Nwonu et al, 2017; Oliveira et al., 2018; Sayilar, 2016; Titus \& Anderson 2018). In other words, the CT suggest that organizing to achieve superior performance is not cast in iron and that organizations whose internal features best match the demands of their environments will achieve the best adaptation. Hence, experience prosperity.

The main supposition of these theories (DCT \& CT) provide the theoretical justification/explanations for the variables under investigation and the hypotheses formulated. Specifically, DCT been an outside-in and inside-out perspective suggest that organizations desirous of achieving superior performance must develop and deploy renewable internal and external competences that are considered peculiar to it. Furthermore, the contingency theory of fit-as-a-moderator suggest that when the effect-size between two variables is explained by a third, then a moderation effect is achieved. Given the foregoing, this study proposed that innovation capability will influence market share. More so, marketing capability would moderate the relationship between innovation capability and market share.

\subsection{Empirical Review}

\subsubsection{Innovation Capability and Market Share}

Talaja (2013) collected data from 264 Croatian companies that were large and mid-sized to investigate the performance-effect of foreign firms' innovation capability. The study confirmed that firms that possess innovative expertise achieve better performance, and this is irrespective of the size of the company. Further analysis showed the foreign firm had more capability to develop new product and consequently reap better product performance, which improved their market share.

In a similar study, which correlated Talaja's study, was Tuan, Nhan, Giang, and Ngoc (2016) study. The authors collected data from 118 Vietnamese firms in multiple industries, found that all dimension of innovation (marketing, process, organization) had a positive influence on firm performance. Moreover, the author pointed out that a higher degree of innovative activities will generate an increase in the firm's fortune. In a similar study, but focusing on medium-sized businesses in Northern Nigeria, Mohammed et al. (2017) collected data from 280 firms. The result via PLS-SEM showed that innovation capability explained significant variation in firm performance. This findings further upheld the submission of earlier scholars (Jiménez-Jiménez \& Sanz-Valle, 2011), who stated that innovation is a critical factor for firms desirous of attaining business success. 
According to Jiménez-Jiménez \& Sanz-Valle, (2011), the necessary prerequisites for driving firm performance depends on well-designed, developed, and implemented innovations which play the important roles in bringing new ideas, improvement, reduction in the cost of production and increase performance. In other to substantiate the submission of the extant literature on the performance-effect of innovation, Ukpabio et al. (2017) sampled a total of 305 manufacturing mid-sized firms in multiple industries South-west of Nigeria. First, through correlation analysis, all the dimensions of innovation capability (product, process, market, organization) and sale revenue (as a measure of market share) are strong-positive correlates. Second, through hierarchical regression analysis, the results revealed that all the four innovation dimensions were significant contributors to sale revenue. Another study conducted by Mohd and Syamsuriana (2013), was similar to Ukpabio et al. (2017) in title, unit of analysis, measured variables, method of analysis (except that the former was done in Malaysia and later Nigeria). The result showed that innovation capability contributes significantly to firm performance (measured as profitability, market share, sales revenue, labour productivity, and employment). Abiodun (2017) study the relevance of innovation capability. The result found all the dimension of innovation (administrative, process, and product) have a significant positive effect on market share. Abiodun's findings are consistent with prior researches (Atalay et al., 2013; Hung \& Chou 2013; Jaskyte, 2011; Jimenez-Jimenez, 2011; Saunila, Pekkola and Ukko, 2014). In view of this findings, the study proposed that innovation capability will have significant effect on market share.

\subsubsection{The Moderating Effect of Marketing Capability}

To substantiate the relevance of marketing-related capabilities to firms' performance, O'Cass and Weerawardena (2010) collected data from 247 firms. The result by means of PLS-SEM suggests that the significant success recorded by brands was attributed to marketing capabilities. This finding aligned with similar studies that position marketing capability as a significant contributor to both innovative tendencies and market share (Ngo \& O'Cass, 2012a). In a similar study, Takata (2018) also revealed that marketing capability explained significant contribution to market share. Also, Fallah et al. (2018) sampled 92 sale agents to establish the relevance of market orientation. The result via PLS-SEM suggested that all the dimension of market orientation (sales, customer, and inter-departmental collaboration) have contributed significantly to market performance. On its own marketing capability have been identified by scholars to have effect on market performance for several firms as established above.

However, its moderation effect on the association between innovation capability and market share is less attended to in marketing literature in Nigeria. Although one can infer that when organizations develop effective and active outside-in marketing capability (Mu, 2015; Mu et al., 2018), the information gathered can aid process, market, and product innovation capability components which scholars already suggested have significant effect on firm performance. Moreover, the contingency theory affirm the possibility of a moderation effect when it posit that beyond a firm's strategy other contingent factors contributes to firm performance. More specifically the contingency proponents suggest that when the relationship between two variables is strengthened with the introduction of a third variable, a fit-as-a moderator exist (Onamusi et al., 2019). Hence, this study align with this narrative to posit that the interaction between innovation capability and market share will be enhanced with the deployment of marketing capability.

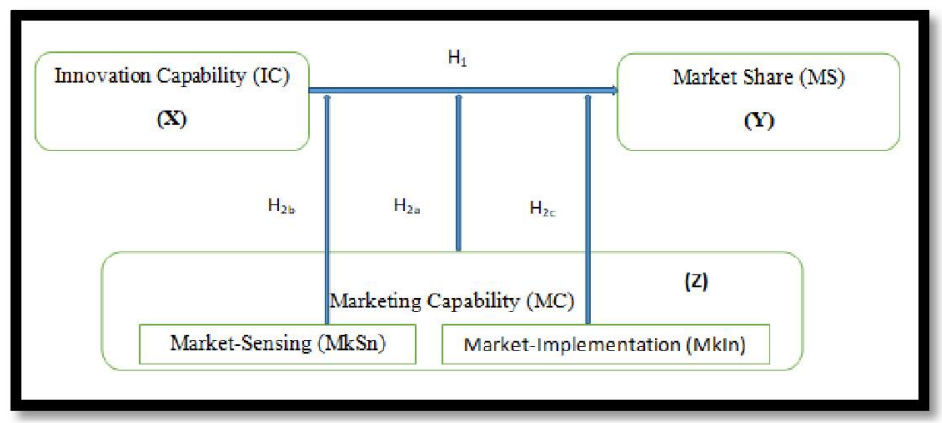

Figure 1: Research Framework

\section{Methodology}

Been an empirical research, this study employed a cross-sectional survey design which involves studying a subset of a population and collecting data at a point in time to determining functional relationship within such a time. A cross-sectional study by implication is cheaper, less time consuming than a longitudinal survey design (Udegbe \& Udegbe, 2013). Many studies have employed this research design and found it appropriate in collecting data to substantiate a relationship or an effect between the independent and dependent variable at a point in time (Abass \& Abu, 2019; Mohammad et al., 2017; Ogbechi et al., 2018; Onamusi et al., 2019).

\subsection{The Study Context, Sampling and Data collection}

The population of this study comprised of 1,012 employees working with Hayat Kimya, Bel Impex, Procter \& Gamble and Wemy Industries. Thus, the sample size appropriate for 1,012 according to Krejcie and Morgan sample size determination table is 278. To accommodate anticipated non-response and inappropriate filling of questionnaires 30\% of the sample size (81) was incorporated into the initial sample size $(278+81=339)$. The category of staff that made up the population are those in the management level in the firms.

The research instrument for data collection was a structured questionnaire. The use of questionnaire is relevant because it helps in collecting feedback based on the perception and opinion of the respondents, more so, it is suitable for 
collecting data from respondents in a short time on current issues, and it is an enabler of quantitative data analysis (Onamusi et al., 2019). The items in the questionnaire were adapted. The adapted questionnaire was a standardized scale that has been used by authors on the subject matter of this research in another research context. The response options provided in this study's questionnaire followed the 6-point Likert type scale ( 1 = strongly disagree, 6 = strongly agree), consistent with (Binuyo et al., 2019).

To enhance the quality of response obtained, the researcher included a question in the bio-data section which requested respondents to rate their knowledge of the overall organizational activities and performance of their company on a scale of 1-10. Hence respondents who ticked six above will be used because it suggests adequate knowledge hence considered appropriate. A similar procedure has been used by scholars to improve the reliability of response obtained for their study (Skarmeas, Zeriti \& Argouslidis, 2019; Sop \& O'Cass, 2015).

The administration and retrieval of the questionnaire took six weeks. After collating the questionnaires, the researcher then screened the questionnaires in such a way that respondents who picked five below on the scale of 1-10 to show their knowledge of the organizational activities and performance, were removed from the lots. In the end, 232 questionnaires were usable representing $68.4 \%$ response rate.

\subsection{Measurement of Variables}

Drawing from this study's research framework, the following dependent (market share), independent (innovation capability), and moderating (marketing capability) variables were discussed taking cognizance of their measurement in extant literature.

\subsubsection{Dependent Variable}

\subsubsection{Market Share (MS)}

Okwachi, Gakure, and Ragui (2013) stated that achieving MS growth is a fundamental business objective and that MS is the percentage of a market accounted for by a specific entity, and can be represented as a firm's sales revenue or as a firm's sales volume in a given market divided by the total volume sales in that market.

Prior studies on organizational performance measured the variable by integrating financial, and non-financial dimension on a multi-item scale, respectively. However, the study observed market share as a financial performance measure. This is because it underline the discussions in the introductory section of the study. It is also a measure of market performance that shows the percentage of a product-line controlled by a company.

\subsubsection{Independent Variable}

\subsubsection{Innovation Capability (IC)}

Spriggs, Yu, Deeeds and Sorenson (2012) consider IC to be a dynamic capability, which firms employ to identify prospects, actions, procedures, willingly share information, encourage dialogue and implement new ideas that result in new products, methods and organisational forms. Prior studies on Innovation capability measured the variable by incorporating both technical and management innovation (Ngo \& O'Cass, 2013). As such this study aligns with extant literature on the measure of innovation capability. This construct was measured using a Likert scale by scholars (such as Camisón \& Villar-López, 2014; Foroudi et al., 2016; Ngo \& O’Cass, 2013).

\subsubsection{Moderating Variable}

\subsubsection{Marketing Capability (MC)}

Chen, Chen and Zhou (2014) posit that MC, is an integrative process of utilizing firm resources (tangible and intangible) to recognize the specific needs of consumers, attain competitive product differentiation and to realize superior brand equity. Marketing capability involves multidimensional tasks. This studies measured marketing capability by incorporating market sensing competency and marketing implementation. These marketing capability dimensions were measured using Likert-type scale in concomitance with earlier scholars (Mu, 2015; Mu et al., 2018; Vorhies \& Morgan, 2005). Overall, this study follow similar procedures used by earlier scholars to measure all the variables identified in this study.

\subsection{Data Analysis}

The study employed a regression analysis to first establish the functional relationship between innovation capability and market share and subsequently established the moderating effect of marketing capability on the relationship using moderated regression analysis.

\subsection{Model Specification}

$Y=f(X)$

$Y=$ Dependent variable: Market performance (measured as Market Share)

$X=$ Independent variables: Innovation Capability

$\mathrm{Z}=$ Moderating variables: Marketing capability (Market sensing (MKSn) and Market implementation(MKIn))

$\mathrm{Y}=\mathrm{f}(\mathrm{X})$

$\mathrm{Y}=\beta \mathrm{o}+\beta_{1} \mathrm{X}_{\mathrm{i}}+\mu_{\mathrm{i}}$

$\mathrm{MS}=\beta \mathrm{o}+\beta_{1} \mathrm{IC}+\mu_{\mathrm{i}}$ 
$\mathrm{Y}=\mathrm{f}(\mathrm{XZ})$

$Y=\beta 0+\beta_{1} X_{i}+\beta_{2} Z_{i}+\beta_{3} X_{Z_{i}}+\mu_{i}$

$M S=\beta 0+\beta_{1} I C_{i}+\beta_{2} M C_{i}+\beta_{3} I_{i}^{*} M^{*} C_{i}+\mu_{i--}$

$\mathrm{MS}=\beta \mathrm{o}+\beta_{1} \mathrm{IC} \mathrm{C}_{\mathrm{i}}+\beta_{2} \mathrm{MKSn}_{\mathrm{i}}+\beta_{3} \mathrm{IC}_{\mathrm{i}}^{*} \mathrm{MKSn}_{\mathrm{i}}+\mu_{\mathrm{i}-}$

$\mathrm{MS}=\beta \mathrm{o}+\beta_{1} \mathrm{IC}_{\mathrm{i}}+\beta_{2} \mathrm{MKI} \mathrm{n}_{\mathrm{i}}+\beta_{3} \mathrm{IC}_{\mathrm{i}}^{*} \mathrm{MKIn}_{\mathrm{i}}+\mu_{\mathrm{i}-}$

For the purpose of this study, the above models were used.

Where:

$\beta o=$ the intercept expected value of $\mathrm{y}$ when $\mathrm{x}$ is equal to zero.

$b=$ the Coefficient of the independent variable (it is the rate of change in y with respect to $\mathrm{x}$ ).

$\mu=$ the error term to accommodate the effect of other variables that can influence organizational performance, but which were not included in the model.

\section{Analysis and Result}

\subsection{Validity and Reliability Test}

Given that the questionnaire used was adapted to fit the peculiarity of this study, the researcher conducted exploratory factor analysis (EFA) to ascertain the overall adequacy and validity of the instrument. A Kaiser-Meyer-Olkin (KMO) statistic greater than 0.72 confirmed the suitability of the items for factor analysis since (Hair, Black, Babin \& Anderson, 2018).The factor loadings of these items were used to establish the Average Variance Extracted (AVE). All the constructs have an AVE value above the threshold 0.5 . The construct, convergent validity and reliability result is presented in Table 1 below.

\begin{tabular}{|c|c|c|c|c|c|c|}
\hline $\begin{array}{c}\text { Latent } \\
\text { Variables }\end{array}$ & Notation & Items & Loadings & CA & CR & $\overline{\text { AVE }}$ \\
\hline \multirow[t]{4}{*}{$\begin{array}{l}\text { Innovation } \\
\text { capability }\end{array}$} & IC4 & $\begin{array}{l}\text { Renewed Support for production } \\
\text { unit }\end{array}$ & 0.899 & \multirow[t]{4}{*}{0.825} & \multirow[t]{4}{*}{0.868} & \multirow[t]{4}{*}{0.628} \\
\hline & IC2 & Innovate manufacturing processes & 0.884 & & & \\
\hline & IC6 & Quality management system & 0.737 & & & \\
\hline & IC3 & Innovate business process & 0.615 & & & \\
\hline \multirow{4}{*}{$\begin{array}{l}\text { Marketing } \\
\text { Capability: } \\
\text { Sensing }\end{array}$} & MC3 & Know competitors' pricing tactics & 0.831 & \multirow[t]{4}{*}{0.779} & \multirow[t]{4}{*}{0.855} & \multirow[t]{4}{*}{0.597} \\
\hline & MC2 & Anticipate market trends & 0.812 & & & \\
\hline & MC4 & Monitor competitors' price changes & 0.721 & & & \\
\hline & MC1 & Alert to market dynamics & 0.72 & & & \\
\hline \multirow[t]{4}{*}{$\begin{array}{l}\text { :Market } \\
\text { Implementation }\end{array}$} & MC11 & $\begin{array}{l}\text { Allocate marketing resources } \\
\text { effectively }\end{array}$ & 0.849 & \multirow[t]{4}{*}{0.793} & \multirow[t]{4}{*}{0.865} & \multirow[t]{4}{*}{0.618} \\
\hline & MC8 & SSegment market & 0.836 & & & \\
\hline & MC7 & Support sales Reps & 0.833 & & & \\
\hline & MC6 & Manage corporate image & 0.602 & & & \\
\hline \multirow[t]{4}{*}{ Market share } & MS3 & Desired sales growth & 0.895 & \multirow[t]{4}{*}{0.763} & \multirow[t]{4}{*}{0.844} & \multirow[t]{4}{*}{0.58} \\
\hline & MS1 & Acquire new customers & 0.771 & & & \\
\hline & MS4 & Open new market & 0.743 & & & \\
\hline & MS2 & Desired market share & 0.61 & & & \\
\hline
\end{tabular}

Table 1: Validity and Reliability Test for Measurement Items.

Note $C A=$ Cronbach Alpha, $C R=$ Composite Reliability, AVE= Average Variance Explained Source: Author's Computation Using SPSS V23

\subsection{Hypotheses Testing}

\begin{tabular}{|c|c|c|c|c|c|c|c|c|}
\hline \multirow[t]{2}{*}{ Model } & \multirow[t]{2}{*}{ Predictors } & \multirow[t]{2}{*}{$\mathbf{R}^{2}$} & \multirow{2}{*}{$\begin{array}{l}\text { Adjusted } \\
\text { R2 }\end{array}$} & \multicolumn{5}{|c|}{ Change Statistics } \\
\hline & & & & $\Delta R^{2}$ & $\Delta F$ & df1 & df2 & Sig. F Change \\
\hline $1 \mathrm{a}$ & IC & $0.221^{\mathrm{a}}$ & 0.218 & 0.221 & 66.279 & 1 & 233 & 0.000 \\
\hline 2 & $\mathrm{IC} * \mathrm{MC}$ & $0.242^{\mathrm{b}}$ & 0.235 & 0.02 & 6.205 & 1 & 232 & 0.013 \\
\hline $1 \mathrm{a}$ & IC & $0.221^{c}$ & 0.218 & 0.221 & 66.279 & 1 & 233 & 0.000 \\
\hline 3 & $\mathrm{IC} * \mathrm{MkSen}$ & $0.224^{\mathrm{d}}$ & 0.217 & 0.003 & 0.775 & 1 & 232 & 0.380 \\
\hline $1 \mathrm{a}$ & IC & $0.221^{\mathrm{e}}$ & 0.218 & 0.221 & 66.279 & 1 & 233 & 0.000 \\
\hline 4 & IC * MkImp & $0.285^{f}$ & 0.279 & 0.064 & 20.643 & 1 & 232 & 0.000 \\
\hline
\end{tabular}

\section{Table 2: Model Summary}

Source: Author's Computation Using SPSS V23.

Note: a. Predictors: (Constant), Innovation capability

b. Predictors: (Constant), Innovation capability*Marketing capability

e. Predictors: (Constant), Innovation capability

f. Predictors: (Constant), Innovation capability*Market implementation 
In the first step (Model 1), the effect of innovation capability on market share was examined. In the Second step (Model 2), the moderating effect of marketing capability (combine-effect) on the interaction between innovation capability and market share were examined. In an attempt to establish which component of marketing capability has the better relative moderating effect, Model 3 and 4 was considered to answer this quest. In the third step (Model 3), the moderating effect of market sensing on the interaction between innovation capability and market share was examined and in the fourth step (Model 4), the moderating effect of market implementation on the interaction between innovation capability and market share was examined and discussed in four paragraphs below.

\subsubsection{Model One}

Effect of innovation capability and market share. Innovation capability accounted for $22.1 \%$ of the variance observed in market share $\left(\mathrm{R}^{2}=0.221, \mathrm{~F}_{(1,233)}=66.279, \beta=0.460, \mathrm{t}=8.141, \mathrm{p}=0.000\right)$ while the remaining $77.9 \%$ is accounted for by other variables beyond innovation capability not accounted for by this study. The effect is significant because the p-value generated is less than (0.05) level of significance used for the study.

\subsubsection{Model Two}

Moderating effect of Marketing capability (ZMksen*ZMkimp) on the relationship between Innovation capability and market share.

Marketing capability moderate the relationship between innovation capability and market share significantly (model 2). This is because $R^{2}$ increased from 0.221 to 0.242 and calculated F-ratio increased by $6.205\left(\Delta R^{2}=0.02, \Delta F_{(1,232)}=6.205\right.$, $p=$ 0.013).This signifies that $24.2 \%$ of the variance observed in performance is accounted for by both innovation capability and the joint integration between marketing sensing and market implementation. The implication of this is that when relevant information gotten from market sensing adequately implemented, the relationship between innovation capability and market share is further enhanced.

\subsubsection{Model Three}

Moderating effect of Market sensing on Innovation capability and market share When the moderator market sensing was added to the regression model (model 1a), market share increased by $0.3 \%$ because $\mathrm{R}^{2}$ increased from 0.221 to 0.224 and calculated F-ratio increased by $0.775\left(\Delta \mathrm{R}^{2}=0.003, \Delta \mathrm{F}(1,232)=0.775 \mathrm{p}=0.380\right)$.This indicates that market sensing has an insignificant moderating effect on the relationship between Innovation capability and market share.

\subsubsection{Model Four}

Moderating effect of Market implementation on Innovation capability and Market share When the moderator market implementation was added to the original regression model (model 1a), market share increased by $6.4 \%$ because $\mathrm{R}^{2}$ increased from 0.221 to 0.285 and calculated F-ratio increased by $20.643\left(\Delta \mathrm{R}^{2}=0.064, \Delta \mathrm{F}_{(1,232)}=20.643, \mathrm{p}=0.000\right)$. This indicates that market implementation has a significant moderatingeffect on the relationship between innovation capability and market share.

\begin{tabular}{|c|c|c|c|c|c|c|}
\hline \multirow[t]{2}{*}{ Dep-Variable } & \multirow{2}{*}{\multicolumn{2}{|c|}{ Model }} & \multicolumn{2}{|c|}{$\begin{array}{l}\text { Unstandardized } \\
\text { Coefficients }\end{array}$} & \multirow[t]{2}{*}{$\mathbf{t}$} & \multirow[t]{2}{*}{ Sig. } \\
\hline & & & $\mathrm{B}$ & Std. Error & & \\
\hline \multirow[t]{11}{*}{ Performance } & \multirow[t]{2}{*}{1} & (Constant) & 2.374 & .281 & 8.455 & .000 \\
\hline & & Innovation capability & .460 & .057 & 8.141 & .000 \\
\hline & \multirow[t]{3}{*}{2} & (Constant) & 2.467 & .280 & 8.803 & .000 \\
\hline & & Innovation capability & .447 & .056 & 7.957 & .000 \\
\hline & & Marketing capability & -.104 & .042 & -2.491 & .013 \\
\hline & \multirow[t]{3}{*}{3} & (Constant) & 2.276 & .303 & 7.523 & .000 \\
\hline & & Innovation capability & .421 & .072 & 5.822 & .000 \\
\hline & & Market sensing & .062 & .070 & .880 & .380 \\
\hline & 4 & (Constant) & 1.928 & .287 & 6.718 & .000 \\
\hline & & Innovation capability & .283 & .067 & 4.244 & .000 \\
\hline & & Market implementation & .284 & .063 & 4.543 & .000 \\
\hline
\end{tabular}

Table 3: Coefficients

Source: Author's Computation Using SPSS V23

\section{Discussion, Conclusion, and Recommendation}

The study examined the effect of innovation capability on market s hare and the moderating effect of marketing capability on the association between innovation and market share. The findings align with hypotheses one and two. The first hypothesis suggested that innovation capability would positively influence market share. This study shows that innovation capability significantly influenced market share. This study corroborate the findings of prior studies (Anning-Dorson, 2018; Mohammed et al., 2017; Ngo et al., 2019; Turulja \& Bajgoric, 2019), which posit that innovation capability has positive significant effect on firm performance.

The second hypothesis presents interesting results. Marketing capability moderated the relationship between innovation and market share, however, on which marketing capability dimension (market sensing and market implementation) presents higher moderating effect, each of the component were introduced respectively. The result revealed that market implementation possess significant moderating effect has its interaction on the innovation-market share relationship grew by 
6.4\%, however market sensing has insignificant moderating effect when introduced. This finding showed that beyond sensing what the market desires, organizations must be able to implement its marketing strategies because all the information gathered through sensing can become fruitful through proper planning and subsequently implementation. The relevance of this study to theory is that it by its result, the contingency perspective is strengthened in the sense that where the strength of the interaction between two variables is enhanced by the introduction of a third variable (in this case marketing capability) then a contingency theory of fit-as-moderator holds. This study strongly affirms this position with its result.

This study conclude that innovation capability have a concomitant effect on market share of manufacturers of baby diaper in Lagos State Nigeria, more so marketing capability (sensing and implementation) moderate the interaction. On the strength of this result, this study recommend that the manufacturers of baby-diaper in Lagos State, Nigeria should invest more in developing an innovative high-level capability that would help their firms to develop new market, which will improve their market performance. Moreover, there is the need to pay attention to developing more dynamic marketing capability from an outside-in perspective such that it enhances the effect innovation capability has on market performance.

\section{References}

i. Abbas, U. I., \& Abu, M. M. (2019). Impact of financial control mechanisms on profitability performance: A case of manufacturing firms in Nigeria. International Journal of Managerial Studies and Research, 7(3), 1-10.

ii. Abiodun, T. S. (2017). An examination of the relationships between different types of innovation and firm performance and the mediating effect of radical and incremental Innovations on these relationships. International Journal of Innovation and Economic Development, 3(1), 38-58.

iii. Adeoye, I. A., Agbawodikeizu, J., \& Egwakhe, A. J. (2019). Innovation adoption determinants and competitive advantage of selected SMEs in Ado- Ota, Ogun state, Nigeria. International Journal of Advanced Engineering, Management and Science, 5(4), 282-289.

iv. Anning-Dorson, T. (2018). Innovation and competitive advantage creation. International Marketing Review, 35(4), 580600 .

v. Aramburu, N., \& Sáenz, J. (2011). Structural capital, innovation capability, and size effect: An empirical study.Journal of Management \& Organization, 17(3), 307-325.

vi. Assink, M. (2006). Inhibitors of disruptive innovation capability: A conceptual model. European Journal of Innovation Management, 9(2), 215-233.

vii. Atalay, M., Anafarta, N., \& Sarvan, F. (2013). The relationship between innovation and firm performance: An empirical evidence from Turkish automotive supplier industry. Procedia - Social and Behavioral Sciences, 75, $226-235$.

viii. Balarabe, S., Lily, J. A., \& Shamsul, H. A. (2017). The influence of marketing capability on firm performance: An empirical evidence from Nigeria. European Journal of Business and Management, 9(32), 147-154.

ix. Barney, J. (1991). Firm resources and sustained competitive advantage. Journal of Management, 17(1), 99-120.

x. Becerril-Arreola, R., Zhou, C., Srinivasan, R., \& Seldin, D. (2017). Service satisfaction-Market share relationships in partnered hybrid offerings. Journal of Marketing, 81(5), 86-103.

xi. Binuyo, A., Ekpe, H., \& Oloyede Binuyo, B. (2019). Innovative strategies and firm growth: Evidence from selected fast moving consumer goods firms in Lagos state, Nigeria. Problems and Perspectives in Management, 17(2), 313-322.

xii. Binti Taju Rahim, F., \& Bin Zainuddin, Y. (2017). Moderating effect of environmental turbulence on firm's technological innovation capabilities (TIC) and business performance in the automotive industry in Malaysia: A conceptual framework. MATEC Web of Conferences, 90, 01009

xiii. Boyd, B. K., Takacs Haynes, K., Hitt, M. A., Bergh, D. D., \& Ketchen, D. J. (2011). Contingency hypotheses in strategic management research. Journal of Management, 38(1), 278-313.

xiv. Bowen, F. E., Rostami, M., \& Steel, P. (2010). Timing is everything: A meta-analysis of the relationships between organizational performance and innovation. Journal of Business Research, 63(11), 1179-1185.

xv. Brahmane, J. (2014). An empirical study on sales capability and marketing implementation capability of SMEs in India and their impact on market share. IOSR Journal of Business and Management, 16(11), 07-16.

xvi. Camisón, C., \& Villar-López, A. (2014). Organizational innovation as an enabler of technological innovation capabilities and firm performance. Journal of Business Research, 67(1), 2891-2902.

xvii. Chen, X. S., Chen, A. X., \& Zhou, K. Z. (2014). Strategic orientation, foreign parent control, and differentiation capability building of international joint ventures in an emerging Market. Journal of International Marketing, 14(7), 10-18.

xviii. Chukwuemeka, O.W., \& Onuoha, B.C. (2018). Dynamic capabilities and competitive advantage of fast foods restaurants. International Journal of Management Science and Business Administration, 4(3), 7-14.

xix. Day, G. S. (1994). The capabilities of market-driven organizations. Journal of Marketing, 58(4), 37-52.

xx. Day, G. S. (2011). Closing the marketing capabilities gap. Journal of Marketing, 75(4), 183-195.

xxi. Day, G. S. (2014). An outside-in approach to resource-based theories. Journal of the Academy of Marketing Science, 42(1), 27-28.

xxii. Dutta, S., Narasimhan, O., \& Rajiv, S. (1999). Success in high-technology markets: Is marketing capability critical? Marketing Science, 18(4), 547-68.

xxiii. Edeling, A., \& Himme, A. (2018). When does market share Matter? New empirical generalizations from a meta-analysis of the market share-performance relationship. Journal of Marketing, 82(3), 1-24.

xxiv. Fallah, H., Jafariyan, H., \& Savabieh, S. (2018). Investigation of market orientation and self-efficacy effects on sale force performance: Mediator role of sales force creativity and innovation implementation. Journal of Relationship Marketing, 17(3), 188-203. 
xxv. Fidel, P., Schlesinger, W., \& Cervera, A. (2015). Collaborating to innovate: Effects on customer knowledge management and performance. Journal of Business Research, 68(7), 1426-1428.

xxvi. Foroudi, P., Jin, Z., Gupta, S., Melewar, T., \& Foroudi, M. M. (2016). Influence of innovation capability and customer experience on reputation and loyalty. Journal of Business Research, 69(11), 4882-4889.

xxvii. Gunday, G., Ulusoy, G., Kilic, K., \& Alpkan, L. (2011). Effect of innovation types on firm performance. International Journal of Production Economics, 133(2), 662-676.

xxviii. Hair, J.F., Black, W.C., Babin, B.J., \& Anderson, R. E. (2018), Multivariate data analysis, 8th ed., Cengage Learning, EMEA, Andover, Hampshire.

xxix. Hung, K. \& Chou, C. (2013). The impact of open innovation on firm performance: The moderating effects of internal R\&D and environmental turbulence. Technovation, 33(10), 368-380.

xxx. Jaskyte, K. (2011). Predictors of administrative and technological innovations in non-profit organizations. Public Administration Review, 71(1), 77-86.

xxxi. Jiménez-Jiménez, D., \& Sanz-Valle, R. (2011). Innovation, organizational learning, and performance. Journal of Business Research, 64(4), 408-417.

xxxii. Kaur, V., \& Mehta, V. (2017). Dynamic capabilities for competitive advantage: A comparative study of IT multinationals in India. Paradigm, 21(1) 31-51.

xxxiii. Kim, N., Shin, S., \& Min, S. (2016). Strategic marketing capability: Mobilizing technological resources for new product advantage. Journal of Business Research, 69(12), 5644-5652.

xxxiv. Lee, P., Wu, M., Kuo, C., \& Li, C. J. (2016). How to deploy multiunit organisations' dynamic capabilities? Management Decision, 54(4), 965-980.

xxxv. Lee, R., Lee, J., \& Garrett, T. C. (2017). Synergy effects of innovation on firm performance. Journal of Business Research, Journal of Business Research, 69(4), 677-684.

xxxvi. Mu, J. (2015). Marketing capability, organizational adaptation and new product development performance. Industrial Marketing Management, 49, 151-166.

xxxvii. Mu, J., Bao, Y., Sekhon, T., Qi, J., \& Love, E. (2018). Outside-in marketing capability and firm performance. Industrial Marketing Management, 75, 37-54.

xxxviii. Mohammed, N. I., Norshahrizan, B. N., \& Wan-Ahmad, B.W. (2017). Innovation capability and firm performance relationship: A study of partial least square-structural equation modelling. International Journal of Organization \& Business Excellence, 2(1), 1-12.

xxxix. Monday, J. U., Akinola, G. O., Ologbenla, P., \& Aladeraji, O. K. (2015). Strategic management and firm performance: A study of selected manufacturing companies in Nigeria. European Journal of Business and Management 7(2), 161-171.

xl. Ngo, L. V., Bucic, T., Sinha, A., \& Lu, V. N. (2019). Effective sense-and-respond strategies: Mediating roles of exploratory and exploitative innovation. Journal of Business Research, 94, 154-161.

xli. Ngo, L.V., \& O'Cass, A. (2012). In search of innovation and customer-related performance superiority: The role of market orientation, marketing capability, and innovation capability interactions.Journal of Product Innovation Management, 29(5), 861-877.

xlii. Nwonu, C. O., Agbaeze, E. K., \& Obi-Anike, H. O. (2017). Effect of organizational structure on performance of selected manufacturing companies in Enugu state Nigeria. The International Journal of Business \& Management, 5(5), $190-206$.

xliii. O'Cass, A., \& Weerawardena, J. (2010). The effects of perceived industry competitive intensity and marketing-related capabilities: Drivers of superior brand performance. Industrial Marketing Management, 39(4), 571-581.

xliv. Ogbechi, A. D., Okafor, L, I., \& Onifade, T. A. (2018). Determinants of customer satisfaction and loyalty in relation to corporate performance of insurance industry in Nigeria. International Journal of Economics, Commerce and Management, 6(4), 201-218.

xlv. Okwachi, S., Gakure, R., \& Mary, R., (2013). Business models- What is their effect on the implementation of strategic plans by SMEs? Prime Journal of Business Administration and Management,3(5), 1025-1032.

xlvi. Oliveira, J. S., Yazdani, N., Cadogan, J. W., Hodgkinson, I. R., Tsougkou, E., Jean, R., Boso, N. (2018). The empirical link between export entry mode diversity and export performance: A contingency- and institutional-based examination. Journal of Business Research, 88, 505-512.

xlvii. Onamusi, A. B., Asikhia, O. U., \& Makinde, G. O. (2019). Environmental munificence and service firm performance. The moderating role of management innovation capability. Paper presented at $3^{\text {rd }}$ international conference on business re-engineering and economic development: Converging transformative marketing and managementPanacea for accelerated firm and economic growth, department of business administration \& marketing, Babcock University Ilisan-Remo, Ogun State, Nigeria.

xlviii. O'Regan, N. (2002). Market share: The conduit to future success? European Business Review, 14(4), $287-293$.

xlix. Salvadó, J. A., De Castro, G. M., López, J. E., \& Verde, M. D. (2013). Environmental innovation and firm performance. International Business Review, 34 (11), 46-58.

l. Saunila, M., Pekkola, S., \& Ukko, J. (2014). The relationship between innovation capability and performance. International Journal of Productivity and Performance Management, 63(2), 234-249.

li. Sayilar, Y. (2016). The past, present and future of structural contingency theory. International Business Review, 23(10), 1423-1437.

lii. Skarmeas, D., Zeriti, A., \& Argouslidis, P. (2019). Importer and exporter capabilities, governance mechanisms, and environmental factors determining customer-perceived relationship value. Industrial Marketing Management, 78, 158168. 
liii. Song, M., Droge, C., Hanvanich, S., \& Calantone, R. (2005). Marketing and technology resource complementarity: an analysis of their interaction effect in two environmental contexts. Strategic Management Journal, 26(3), 259-76.

liv. Song, M., Nason, R., \& Di Benedetto, C. A. (2008). Distinctive marketing and information technology capabilities and strategic types: A cross-national investigation. Journal of International Marketing, 16(1), 4-38.

lv. Sok, P., \& O'Cass, A. (2015). Examining the new product innovation - performance relationship: Optimizing the role of individual-level creativity and attention-to-detail. Industrial Marketing Management, 47, 156-165.

lvi. Takata, H. (2018). Transaction costs and capability factors in dual or indirect distribution channel selection: An empirical analysis of Japanese manufacturers. Industrial Marketing Management, Journal of Business Research, 84(4), 146-158.

lvii. Talaja, A. (2013). Innovative capabilities, firm performance and foreign ownership: Empirical analysis of large and medium-sized companies form all industries. Business and Economic Horizons, 9(3), 69-78.

lviii. Teece, D. J. (2014a). A dynamic capabilities-based entrepreneurial theory of the multinational enterprise. Journal of International Business Studies, 45(1), 8-37.

lix. Titus, V. K., \& Anderson, B. S. (2018). Firm structure and environment as contingencies to the corporate venture capitalparent firm value relationship. Entrepreneurship Theory and Practice, 42(3), 498-522.

lx. Trainor, K. J., Rapp, A., Beitelspacher, L. S., \& Schillewaert, N. (2011). Integrating information technology and marketing: An examination of the drivers and outcomes of e-marketing capability. Industrial Marketing Management, 40(1), 162174.

lxi. Tuan, N., Nhan, N., Giang, P., \& Ngoc, N. (2016). The effects of innovation on firm performance of supporting industries in Hanoi, Vietnam. Journal of Industrial Engineering and Management, 9(2), 413-426.

lxii. Turulja, L., \& Bajgoric, N. (2019). Innovation, firms' performance and environmental turbulence: is there a moderator or mediator? European Journal of Innovation Management, 22(1), 213-232.

lxiii. Udegbe, S., \& Udegbe, M. (2013). Impact of product development and innovation on organisational performance. International Journal of Management and Sustainability, 2(12), 220-230.

lxiv. Ukpabio, M. G., Oyebisi, T. O., \& Siyanbola, W.O., (2017). Technological innovation and performance of manufacturing firms in Nigeria. International Journal of Innovative Research and Advanced Studies,4(11), 201-217.

lxv. Ukko, J., Saunila, M., Parjanen, S., Rantala, T., Salminen, J., Pekkola, S., \& Mäkimattila, M. (2016). Effectiveness of innovation capability development methods. Innovation, 18(4), 513-535.

lxvi. Vorhies, D.W., \& Morgan, N. A. (2005). Benchmarking marketing capabilities for sustainable competitive advantage. Journal of Marketing, 69(1), 80-94.

lxvii. Wallin, J., Larsson, A., Isaksson, O., \& Larsson, T. (2011). Measuring innovation capability-Assessing collaborative performance in product-service system innovation. Functional Thinking for Value Creation, 14(3), 207-212.

lxviii. Wang, G., \& Miao, C. F. (2015). Effects of sales force market orientation on creativity, innovation implementation, and sales performance. Journal of Business Research, 68(11), 2374-2382.

lxix. Zhang, M., \& Hartley, J. L. (2018). Guanxi, IT systems, and innovation capability: The moderating role of proactiveness. Journal of Business Research, 90(5), 75-86. 